\title{
HUBUNGAN PERILAKU DAN LINGKUNGAN RUMAH DENGAN TB PARU DI WILAYAH KERJA PUSKESMAS PANYABUNGAN JAE
}

\author{
Kurnia Alamsyah ${ }^{1}$, Santy Deasy Siregar ${ }^{*}$, Herbert Wau \\ Fakultas Kesehatan Masyarakat, Universitas Prima Indonesia \\ *email: santysiregar76@yahoo.com
}

\begin{abstract}
ABSTRAK
Tuberkulosis Paru atau TB Paru merupakan penyakit infeksi menular yang menyerang paru-paru dan bronkus. Penyakit ini disebabkan oleh mycobacterium tuberculosis yang menyebar melalui udara kesaluran pernapasan manusia.Pada tahun 2017 diperoleh angka Case Notification Rate/CNR (kasus baru) TB Paru BTA (+) di Sumatera Utara sebesar 104,3 / 100.000 penduduk dan Kabupaten Mandailing Natal menjadi daerah urutan kedua dengan CNR sebesar 187 / 100.000 penduduk. Salah satu faktor yang dapat mempengaruhi kesembuhan TB Paru diantaranya adalah perilaku seperti pengetahuan, sikap dan tindakan serta lingkungan seperti luas ventilasi dan kepadatan hunian. Tujuan penelitian ini adalah untuk mengetahui hubungan perilaku dan lingkungan rumah terhadap kejadian TB Paru di Wilayah Kerja Puskesmas Panyabungan Jae Tahun 2019. Jenis penelitian ini menggunakan metode survey analitik dengan pendekatan cross sectional. Sampel dalam penelitian ini adalah sebanyak 56 orang yang diambil dengan teknik total sampling. Hasil penelitian didapatkan bahwa mayoritas responden memiliki pengetahuan kurang, sikap negatif, tindakan tidak baik, luas ventilasi rumah tidak memenuhi syarat dan kepadatan hunian yang padat dengan mayoritas adanya kejadian TB Paru. Hasil uji bivariat didapatkan bahwa ada hubungan antara pengetahuan $(p=0,003)$, sikap $(p=0,010)$, tindakan $(p=0,013)$, luas ventilasi $(p=0,003)$ dan $\operatorname{kepadatan}(p=0,017)$ dengan kejadian TB Paru di wilayah kerja Puskesmas Panyabungan Jae. Diharapkan kepada masyarakat di wilayah Puskesmas Panyabungan Jae untuk lebih aktif melakukan pemeriksaan dan pengobatan TB Baru serta mengikuti tatalaksana TB Paru yang diberikan oleh petugas pelayanan kesehatan. Untuk peneliti selanjutnya diharapkan untuk dapat mengembangkan penelitian tentang faktor-faktor terjadinya penyakit TB Paru di suatu wilayah
\end{abstract}

Kata Kunci : Perilaku, Lingkungan, Tuberkulosis Paru

\section{ABSTRACT}

Pulmonary tuberculosis or pulmonary tuberculosis is a contagious infectious disease that attacks the lungs and bronchi. This disease is caused by mycobacterium tuberculosis which spreads through the air of human respiratory discharges. In 2017, the figure of Case Notification Rate / CNR (new case) of pulmonary TB (+) in North Sumatra was 104.3 / 100,000 population and Mandailing Natal District became an area second place with CNR of 187 / 100,000 population. One of the factors that can affect the recovery of pulmonary TB include behaviors such as knowledge, attitudes and actions as well as the environment such as ventilation area and occupancy density. The purpose of this study was to determine the relationship of behavior and home environment to the incidence of pulmonary TB in Panyabungan Jae Public Health Center in 2019. This type of research uses analytic survey method with cross sectional approach. The sample in this study were 56 people taken by total sampling technique. The results showed that the majority of respondents have less knowledge, negative attitudes, actions are not good, the area of ventilation of the house does not meet the requirements and the density of dense occupancy with the majority of the occurrence of pulmonary TB. Bivariate test results found that there is a relationship between knowledge $(p=0.003)$, attitude $(p=0.010)$, actions $(p=0.013)$, ventilation area $(p=0.003)$ and density $(p=0.017)$ with the incidence of pulmonary TB in the Panyabungan Jae Public Health Center. It is expected that the community in the Panyabungan Jae Puskesmas area will be more active in carrying out the examination and treatment of new TB and following the management of pulmonary TB provided by health care workers. The next researcher is expected to be able to develop research on the factors that cause pulmonary TB in a region

\section{Keywords: Behavior, Environment, Lung Tuberculosis}

\section{PENDAHULUAN}

Tuberkulosis (TB) adalah suatu penyakit infeksi menular yang disebabkan bakteri Mycobacterium tuberculosis, yang dapat menyerang berbagai organ, terutama paruparu. Penyakit ini bila tidak diobati atau pengobatannya tidak tuntas dapat menimbulkan komplikasi berbahaya hingga kematian. $^{1}$
Tuberkulosis (TB) sampai saat ini masih merupakan permasalahan kesehatan di masyarakat, bukan hanya karena TB adalah penyakit menular, namun ada hubungan TB dengan penyakit tidak menular lainnya seperti pada Diabetes Mellitus, penyakit akibat rokok, alkhohol, pengguna narkoba dan malnutrisi. TB sebagian besar menyerang pada usia produktif dan masyarakat dengan sosial ekonomi yang kurang menguntungkan. TB 
menjadi penyebab tersering untuk kesakitan dan kematian pada Orang dengan HIV AIDS. TB sering dihubungkan dengan kemiskinan, lingkungan yang kumuh, padat dan terbatasnya akses untuk perilaku hidup bersih dan sehat. Wanita hamil dan anak anak juga sangat rentan terkena TB. ${ }^{2}$

Sebanyak $1 / 3$ kasus TB masih belum terakses atau dilaporkan. Bahkan sebagian besar kasus TB terlambat ditemukan sehingga saat diagnosa ditegakkan mereka sudah dalam tahap lanjut bahkan kuman telah resistan obat sehingga sulit untuk diobati. Keterlambatan pengobatan ini bermakna karena menunjukkan lebih banyak lagi penduduk yang sudah terpapar TB. Kesadaran masyarakat untuk mencari pengobatan secara dini sangatlah penting, oleh sebab itu diperlukan peran serta masyarakat.dan strategi kunci untuk dapat menemukan sepertiga kasus TB yang 'hilang' dan tidak terlaporkan serta untuk menjangkau kasus TB pada kelompok rentan adalah dengan melibatkan masyarakat secara aktif dalam program pengendalian TB. ${ }^{2}$

Tuberkulosis merupakan penyakit yang menjadi perhatian global. Sesuai dengan Tujuan Pembangunan Berkelanjutan 2030, WHO menargetkan untuk menurunkan kematian akibat tuberkulosis sebesar $90 \%$ dan menurunkan insidens sebesar $80 \%$ pada tahun 2030 dibandingkan dengan tahun 2014. ${ }^{3}$

Eliminasi TB akan tercapai bila angka insidensi TB berhasil diturunkan mencapai 1 kasus TB per 1 juta penduduk, sedangkan kondisi yang memungkinkan pencapaian eliminasi TB(pra eliminasi) adalah bila angka insidensi mampu dikurangi menjadi 10 per 100.000 penduduk. Dengan angka insidensi global tahun 2012 mencapai 122 per 100.000 pendudukdan penurunan angka insidensi sebesar $1-2 \%$ setahun maka TB akan memasuki kondisi praeliminasi pada tahun $2160 .^{2}$

Data penderita TB di dunia, Pada tahun 2015 terdapat 10,4 juta kasus baru tuberkulosis atau 142 kasus/100.000 populasi, dengan 480.000 kasus multidrug-resistant. Indonesia merupakan negara dengan jumlah kasus baru terbanyak kedua di dunia setelah India. Sebesar $60 \%$ kasus baru terjadi di 6 negara yaitu India, Indonesia, China, Nigeria, Pakistan dan Afrika Selatan. Kematian akibat tuberkulosis diperkirakan sebanyak 1,4 juta kematian ditambah 0,4 juta kematian akibat tuberkulosis pada orang dengan HIV. Meskipun jumlah kematian akibat tuberkulosis menurun 22\% antara tahun 2000 dan 2015, tuberkulosis tetap menjadi 10 penyebab kematian tertinggi di dunia pada tahun $2015 .{ }^{4}$

Data penderita TB Paru di Indonesia, Angka pervalensi TB pada tahun 2014 menjadi sebesar 647/100.000 penduduk meningkat dari 272/100.000 penduduk pada tahun sebelumnya, angka insidensi tahun 2014 sebesar 399/100.000 penduduk dari sebelumnya sebesar 183/100.000 penduduk pada tahun 2013, demikian juga dengan angka mortalitas pada tahun 2014 sebesar $41 / 100.000$ penduduk dari 25/100.000 penduduk pada tahun 2013. Pada tahun 2015 ditemukan jumlah kasus tuberkulosis sebanyak 330.910 kasus, meningkat bila dibandingkan semua kasus tuberkulosis yang ditemukan pada tahun 2014 yang sebesar 324.539 kasus. $^{1}$

Berdasarkan jumlah kasus Tuberkulosis semua tipe menurut jenis kelamin pada tahun 2017 Provinsi Sumatera Utara termasuk kedalam urutan kelima tertinggi kasus Tuberkulosis sebanyak 20.429 orang, dimana Provinsi tertinggi pertama yaitu Provinsi Jawa Barat sebanyak 78.698 orang dengan BTA+, Provinsi kedua yaitu Provinsi Jawa Timur sebanyak 48.323 orang, Provinsi ketiga yaitu Jawa Tengah sebanyak 42.272 orang, Provinsi keempat yaitu DKI Jakarta sebanyak 35.733 orang.

Berdasarkan jumlah kasus Tuberkulosis semua tipe menurut jenis kelamin pada tahun 2018 Provinsi Sumatera Utara termasuk kedalam urutan kelima tertinggi kasus Tuberkulosis sebanyak 32.651 orang, dimana Provinsi tertinggi pertama yaitu Jawa Barat sebanyak 99.398 orang, Provinsi kedua yaitu Jawa Tengah sebanyak 67.063 orang, Provinsi ketiga yaitu Jawa Timur sebanyak 56.445 orang, Provinsi keempat yaitu DKI Jakarta sebanyak 36.241 orang. ${ }^{6}$

Pada tahun 2017 diperoleh angka Case Notification Rate/CNR (kasus baru) TB Paru BTA (+) di Sumatera Utara sebesar 104,3 per 100.000. Pencapaian tertinggi CNR diperoleh Kota Sibolga sebesar 192/100.000 penduduk, diikuti Kabupaten Mandailing Natal 187/100.000 penduduk dan Kabupaten Nias sebesar 174/100.000 penduduk. Adapun pencapaian CNR terendah diperoleh Kota Binjai sebesar 22/100.000, diikuti Kabupaten Padang Lawas sebesar 37/100.000 penduduk dan Kabupaten Labuhan Batu Selatan sebesar 40/100.000. ${ }^{7}$

Data kasus TB Paru di Provinsi Sumatera Utara, berdasarkan jumlah penduduk tahun 2014, diperhitungkan sasaran penemuan kasus baru TB Paru BTA (+) di Provinsi Sumatera Utara adalah sebesar 22.026 jiwa, dan hasil cakupan penemuan kasus baru TB 
Paru BTA (+) yaitu 16.818 kasus atau $76,35 \%$. Angka ini mengalami kenaikan bila dibandingkan dengan cakupan penemuan kasus baru tahun 2013 sebesar 72,29\% namun lebih rendah bila dibandingkan dengan tahun 2012 sebesar 82,57\% dan tahun 2011 sebesar $76,57 \% .^{8}$

Hasil survei pendahuluan pada bulan Juli tahun 2019 bahwa Puskesmas Panyabungan Jae belum mencapai target yang telah ditetapkan Dinas Kesehatan Kota Medan yaitu $85 \%$, angka kesembuhan penyakit TB Paru di Puskesmas Panyabungan Jae sebesar $60 \%$. Puskesmas Panyabungan Jae terdiri dari 25 kelurahan, jumlah pasien TB Paru terbanyak terdapat di desa/kelurahan Sipolu-Polu yaitu 21 orang disebabkan kondisi jarak rumah yang terlalu padat sehingga memudahkan dalam penularan penyakit TB Paru dan yang paling sedikit terdapat di desa/kelurahan Panyabungan I, Adian Jior dan Siobon Jae yaitu nihil. Data Pasien TB Paru 6 bulan terakhir yaitu bulan Juli - Desember yang memeriksakan dirinya ke Puskesmas Panyabungan Jae sebanyak 56 orang.

Berdasarkan hasil wawancara yang telah dilakukan oleh peneliti pada tanggal 15 Juli 2019 pukul 08.30 sampai pukul 14.00 di Wilayah Kerja Puskesmas Panyabungan Jae terhadap 5 orang penderita TB Paru bahwa perilaku yang kurang baik menjadi kebiasaan yang dilakukan mereka seperti merokok, personal hygiene. Selain itu, faktor lain yang menyebabkan penderita TB Paru yaitu kepadatan rumah penduduk di desa/kelurahan SiPolu-Polu sehingga kurangnya cahaya sinar matahari dan sirkulasinya buruk atau lembab.

Keberhasilan upaya pengendalian Tubekulosis diukur dengan melihat cakupan penemuan penderita (minimal $83 \%$ dari perkiraan penderita baru BTA positif), angka konversi (>80\%), angka kesembuhan (>85\%) serta angka kesalahan pemeriksaan laboratorium kasus TB error rate $(>5 \%)(8)$. Menurut penelitian Erlin,dkk (2016) di Kota Magelang bahwa terdapat hubungan jenis dinding, suhu dan kelembaban dengan kejadian TB Paru di Kota Magelang. ${ }^{9}$ Menurut penelitian Aviliana,dkk (2015) di Desa Wori Kecamatan Wori Kabupaten Minahasa Utara bahwa terdapat hubungan yang signifikan antara tindakan dengan kejadian Tuberkulosis. ${ }^{10}$

Tujuan penelitian ini adalah untuk meneliti tentang Hubungan Perilaku dan Lingkungan Rumah Dengan Kejadian TB Paru di Wilayah Kerja Puskesmas Panyabungan Jae.

\section{METODE}

Penelitian ini merupakan jenis penelitian yang menggunakan metode survei analitik dengan menggunakan pendekatan cross sectional. Tempat penelitian adalah di Wilayah Kerja Puskesmas Panyabungan Jae di kelurahan/desa Sipolu-polu. Penelitian akan dilakukan pada bulan Januari 2020. Populasi dalam penelitian ini adalah Semua orang/pasien yang dinyatakan positif menderita TB paru dan tercatat sebagai pasien di Puskesmas Panyabungan Jae pada bulan Juli-Desember sebanyak 56 orang dengan BTA Positif (TB Paru). Sampel pada penelitian ini adalah total sampling dimana jumlah sampel sama dengan populasi sebanyak 56 orang.

Pengumpulan data dalam penelitian ini dilakukan dengan wawancara langsung terhadap responden dengan alat bantu kuesoner. Setelah data terkumpul peneliti selanjutnya melakukan analisis data. Analisis data penelitian adalah analisis Univariat dan analisis Bivariat. Uji statistik yang digunakan untuk mengetahui ada tidaknya hubungan antara variabel independen dan variabel dependen adalah uji statistik chi-squre.jika nilai $\mathrm{p}<(0,05)$ maka $\mathrm{Ho}$ ditolak dan $\mathrm{Ha}$ diterima. Artinya ada hubungan antara perilaku (pengetahuan, sikap, tindakan) dan lingkungan rumah dengan pasien TB paru. Sebaliknya jika nilai $P>(0,05)$ maka artinya tidak ada hubungan perilaku (pengetahuan, sikap, tindakan) dan lingkungan rumah dengan pasien TB paru.

HASIL

Analisa Univariat

Karakteristik Responden

Tabel 1: Distribusi Frekuensi Menurut Karakteristik Umur, Jenis Kelamin, Pendidikan, Pekerjaan, Penghasilan, Pengetahuan, Sikap, Tindakan, Luas Ventilasi Kepadatan, dan BTA Responden di Wilayah Kerja Puskesmas Panyabungan Jae

\begin{tabular}{cccc}
\hline No & Umur & Frekuensi (f) & Persentase (\%) \\
\hline 1 & $18-30$ tahun & 9 & 16.1 \\
2 & $31-40$ tahun & 14 & 25.0 \\
3 & $41-50$ tahun & 13 & 23.2 \\
4 & $>50$ tahun & 20 & 35.7 \\
\hline & Total & $\mathbf{5 6}$ & $\mathbf{1 0 0 , 0}$ \\
\hline
\end{tabular}




\begin{tabular}{|c|c|c|c|}
\hline No & Jenis Kelamin & Frekuensi (f) & Persentase (\%) \\
\hline 1 & Perempuan & 15 & 26.8 \\
\hline \multirow[t]{2}{*}{2} & Laki-Laki & 41 & 73.2 \\
\hline & Total & 56 & 100,0 \\
\hline No & Pendidikan & Frekuensi (f) & Persentase $(\%)$ \\
\hline 1 & SD & 11 & 19.6 \\
\hline 2 & SMP & 15 & 26.8 \\
\hline 3 & SMA & 23 & 41.1 \\
\hline \multirow[t]{2}{*}{4} & Sarjana & 7 & 12.5 \\
\hline & Total & 56 & 100,0 \\
\hline No & Pekerjaan & Frekuensi (f) & Persentase (\%) \\
\hline 1 & Buruh & 8 & 14.3 \\
\hline 2 & Petani & 18 & 32.1 \\
\hline 3 & Pedagang & 7 & 12.5 \\
\hline 4 & PNS & 5 & 8.9 \\
\hline 6 & TukangBecak & 3 & 5.4 \\
\hline \multirow[t]{2}{*}{7} & TidakBekerja & 15 & 26.8 \\
\hline & Total & 56 & 100,0 \\
\hline No & Penghasilan & Fekuensi (f) & Persentase (\%) \\
\hline 1 & $>1.500 .000,-$ & 21 & 37.5 \\
\hline \multirow[t]{2}{*}{2} & $<1.500 .000,-$ & 35 & 62.5 \\
\hline & Total & 56 & 100,0 \\
\hline No & Pengetahuan & Frekuensi (f) & Persentase (\%) \\
\hline 1 & Baik & 14 & 25.0 \\
\hline \multirow[t]{2}{*}{2} & Kurang & 42 & 75.0 \\
\hline & Total & 56 & 100,0 \\
\hline No & Sikap & Frekuensi (f) & Persentase (\%) \\
\hline 1 & Positif & 16 & 28.6 \\
\hline \multirow[t]{2}{*}{2} & Negatif & 40 & 71.4 \\
\hline & Total & 56 & 100,0 \\
\hline No & Tindakan & Frekuensi (f) & Persentase (\%) \\
\hline 1 & Baik & 13 & 23.2 \\
\hline \multirow[t]{2}{*}{2} & TidakBaik & 43 & 76.8 \\
\hline & Total & 56 & 100.0 \\
\hline No & Luas Ventilasi & Frekuensi (f) & Persentase $(\%)$ \\
\hline 1 & Baik & 19 & 33.9 \\
\hline \multirow[t]{2}{*}{2} & Kurang & 37 & 66.1 \\
\hline & Total & 56 & 100.0 \\
\hline No & Kepadatan & Frekuensi (f) & Persentase $(\%)$ \\
\hline 1 & Baik & 26 & 46.4 \\
\hline \multirow[t]{2}{*}{2} & KurangBaik & 30 & 53.6 \\
\hline & Total & 56 & 100.0 \\
\hline No & BTA & Frekuensi (f) & Persentase (\%) \\
\hline 1 & Positif & 44 & 78.6 \\
\hline \multirow[t]{2}{*}{2} & Negatif & 12 & 21.4 \\
\hline & Total & 56 & 100,0 \\
\hline
\end{tabular}

Sumber : Data Primer 2019

Berdasarkan tabel 1 di atas diketahui sebagian besar responden berumur $>50$ tahun yaitu sebanyak 20 orang (35.7\%) dan sebagian kecil responden berumur 18-30tahun sebanyak9 orang (16.1\%). Berdasarkan jenis kelamin, sebagian besar responden berjenis kelamin laki-laki yaitu sebanyak41 orang (73.2\%) dan sebagian kecil responden berjenis kelamin perempuan sebanyak15 orang (26.8\%). Berdasarakan pendidikan, sebagian besar responden berpendidikan SMAyaitu sebanyak 23 orang (41.1\%) dan sebagian kecil responden berpendidikan Sarjana yaitu sebanyak7 orang (12.5\%). Berdasarkan pekerjaan, sebagian besar responden bekerja sebagai petani yaitu sebanyak 18 orang (32.1\%) dan sebagian kecil responden bekerja sebagai tukang becak 
yaitu sebanyak 3 orang (5.4\%). Berdasarkan penghasilan, sebagian besar responden berpenghasilan < Rp.1500.000,yaitu sebanyak 35 orang (62.5) dan sebagian kecil responden berpenghasilan > Rp.1.500.000,- yaitu sebanyak 21 orang (37.5\%). Berdasarkan pengetahuan, diketahui sebagian besar responden dengan pengetahuan kurang sebanyak yaitu 42 orang $(75.0 \%)$ dan sebagian kecil responden dengan pengetahuan baik yaitu sebanyak 14 orang (25.0\%). Berdasarkan sikap, diketahui sebagian besar responden dengan sikap negative yaitu sebanyak 40 orang $(71.4 \%)$ dan sebagian kecil responden dengan sikap positif yaitu sebanyak 16 orang (28.6\%). Berdasarkan tindakan, diketahui sebagian besar responden dengan tindakan tidak baik yaitu sebanyak 43orang $(76.8 \%)$ dan sebagian kecil responden dengan tindakan baik yaitu

Analisa Bivariat

Analisis Statistik Pengetahuan Terhadap Penyakit TB Paru

Tabel 2: $\quad$ Hasil Uji Chi-Square Pengetahuan, Sikap, Tindakan, Luas Ventilasi, Kepadatan Terhadap Penyakit TB Paru Pada Pasien TB Paru di Wilayah Kerja Puskesmas Panyabungan Jae

\begin{tabular}{|c|c|c|c|c|c|c|c|}
\hline \multirow{3}{*}{ Pengetahuan } & \multicolumn{6}{|c|}{ BTA } & \multirow{3}{*}{ Nilai $P$} \\
\hline & \multicolumn{2}{|c|}{ Positif } & \multicolumn{2}{|c|}{ Negatif } & \multicolumn{2}{|c|}{ Total } & \\
\hline & $\mathbf{n}$ & $\%$ & $\mathbf{n}$ & $\%$ & $n$ & $\%$ & \\
\hline Kurang & 37 & $88.1 \%$ & 5 & $11.9 \%$ & 42 & $100 \%$ & 0003 \\
\hline Baik & 7 & $50 \%$ & 7 & $50 \%$ & 14 & $100 \%$ & 0.003 \\
\hline & \multicolumn{6}{|c|}{ BTA } & \\
\hline \multirow[t]{2}{*}{ Sikap } & \multicolumn{2}{|c|}{ Positif } & \multicolumn{2}{|c|}{ Negatif } & \multicolumn{2}{|c|}{ Total } & Nilai $P$ \\
\hline & $\mathbf{n}$ & $\%$ & $\mathbf{n}$ & $\%$ & $\mathbf{n}$ & $\%$ & \\
\hline Negatif & 35 & $87.5 \%$ & 5 & $12.5 \%$ & 40 & $100 \%$ & \\
\hline Positif & 9 & $56.3 \%$ & 7 & $43.8 \%$ & 16 & $100 \%$ & 0.010 \\
\hline & \multicolumn{6}{|c|}{ BTA } & \\
\hline \multirow[t]{2}{*}{ Tindakan } & \multicolumn{2}{|c|}{ Positif } & \multicolumn{2}{|c|}{ Negatif } & \multicolumn{2}{|c|}{ Total } & Nilai $P$ \\
\hline & $\mathbf{n}$ & $\%$ & $\mathbf{n}$ & $\%$ & $\mathbf{n}$ & $\%$ & \\
\hline TidakBaik & 37 & $86.0 \%$ & 6 & $14.0 \%$ & 43 & $100 \%$ & 0013 \\
\hline Baik & 7 & $53.8 \%$ & 6 & $46.2 \%$ & 13 & $100 \%$ & 0.013 \\
\hline & \multicolumn{6}{|c|}{ BTA } & \\
\hline \multirow[t]{2}{*}{ Luas Ventilasi } & \multicolumn{2}{|c|}{ Positif } & \multicolumn{2}{|c|}{ Negatif } & \multicolumn{2}{|c|}{ Total } & Nilai $P$ \\
\hline & $\mathbf{n}$ & $\%$ & $\mathbf{n}$ & $\%$ & $\mathbf{n}$ & $\%$ & \\
\hline Kurang & 25 & $67.6 \%$ & 12 & $32.4 \%$ & 37 & $100 \%$ & 0005 \\
\hline Baik & 19 & $100 \%$ & 0 & $0.0 \%$ & 19 & $100 \%$ & 0.005 \\
\hline & \multicolumn{6}{|c|}{ BTA } & \\
\hline \multirow[t]{2}{*}{ Kepadatan } & \multicolumn{2}{|c|}{ Positif } & \multicolumn{2}{|c|}{ Negatif } & \multicolumn{2}{|c|}{ Total } & Nilai $P$ \\
\hline & $\mathbf{n}$ & $\%$ & $\mathbf{n}$ & $\%$ & $\mathbf{n}$ & $\%$ & \\
\hline Kurang Baik & 20 & $66.7 \%$ & 10 & $33.3 \%$ & 30 & $100 \%$ & ח?חת \\
\hline Baik & 24 & $92.3 \%$ & 2 & $7.7 \%$ & 26 & $100 \%$ & 0.020 \\
\hline
\end{tabular}

Sumber : Data Primer 2019

Berdasarkan tabel 2 diatas diketahui sebagian besar responden memiliki pengetahuan kurang yaitu sebanyak 42 orang dengan hasil pemeriksaan BTA positif sebanyak 37 orang (88.1\%) dan BTA negative sebanyak 5 orang (11.9\%). Sedangkan sebanyak 13 orang (23.2\%). Berdasarkan luas ventilasi rumah, diketahui sebagian besar responden memiliki luas ventilasi yang kurang yaitu sebanyak 37orang (66.1\%) dan sebagian kecil responden memiliki luas ventilasi yang baik yaitu sebanyak 19 orang (33.9\%). Berdasarkan kepadatan hunian rumah, diketahui sebagian besar responden memiliki kepadatan hunian yang kurang baik yaitu sebanyak 30 orang $(53.6 \%)$ dan sebagian kecil responden memiliki kepadatan hunian yang baik yaitu sebanyak 26 orang (46.4\%). Berdasarkan pemeriksaan BTA secaradua kali berturut-turut, diketahui sebagian besar responden memiliki hasil pemeriksaan BTA positifyaitu sebanyak 44 orang $(78,6 \%)$ dan sebagian kecil responden memiliki hasil pemeriksaan BTA negative yaitu sebanyak 12 orang $(21,4 \%)$. 
Hasil analisis tabel 2 diatas juga menunjukkan nilai koefisien korelasi antara pengetahuan responden terhadap penyakit TB Paru pada pasien TB Paru di wilayah kerja Puskesmas Panyabungan Jae adalah sebesar 0,003 dengan taraf signifikan $5 \%$ yaitu $p$ Value < a $(0,003<0,05)$, maka $\mathrm{H}_{\circ}$ ditolak dan $\mathrm{H}_{\mathrm{a}}$ diterima. Artinya terdapat hubungan signifikan antara pengetahuan terhadap penyakit TB Paru pada pasien TB Paru di wilayah kerja Puskesmas Panyabungan Jae.

Berdasarkan tabel 2 diatas diketahui sebagian besar responden memiliki sikap negatif sebanyak 40 orang dengan hasil pemeriksaan BTA positif sebanyak 35 orang $(87.5 \%)$ dan BTA negatifsebanyak 5 orang (12.5\%). Sedangkan sebagian kecil responden memiliki sikap positif sebanyak 16 orang dengan hasil pemeriksaan BTA positif sebanyak 9 orang $(56.3 \%)$ dan BTA negative sebanyak 7 orang (43.8\%).

Hasil analisis tabel 2 diatas juga menunjukkan nilai koefisien korelasi antara sikap responden terhadap penyakit TB Paru pada pasien TB Paru di wilayah kerja Puskesmas Panyabungan Jae adalah sebesar 0,010 dengan taraf signifikan $5 \%$ yaitu $p$ Value $<a(0,010<0,05)$, maka $H_{\circ}$ ditolak dan $H_{a}$ diterima. Artinya terdapat hubungan signifikan antara sikap terhadap penyakit TB Paru pada pasien TB Paru di wilayah kerja Puskesmas Panyabungan Jae.

Berdasarkan tabel 2 diatas diketahui sebagian besar responden memiliki tindakan tidak baik sebanyak 43 orang dengan hasil pemeriksaan BTA positif sebanyak 37 orang $(86.0 \%)$ dan BTA negative sebanyak 6 orang $(14.0 \%)$. Sedangkan sebagian kecil responden memiliki tindakan baik sebanyak 13 orang dengan hasil pemeriksaan BTA positif sebanyak 7 orang $(53.8 \%)$ dan BTA negative sebanyak 6 orang (46.2\%).

Hasil analisis tabel 2 diatas juga menunjukkan nilai koefisien korelasi antara tindakan responden terhadap penyakit TB Paru pada pasien TB Paru di wilayah kerja Puskesmas Panyabungan Jae adalah sebesar 0,013 dengan taraf signifikan $5 \%$ yaitu $p$ Value < a $(0,013<0,05)$, maka $\mathrm{H}_{0}$ ditolak dan $\mathrm{H}_{\mathrm{a}}$ diterima. Artinya terdapat hubungan signifikan antara tindakan terhadap penyakit TB Paru pada pasien TB Paru di wilayah kerja Puskesmas Panyabungan Jae.

Berdasarkan tabel 2 diatas diketahui sebagian besar responden memiliki luas ventilasi kurang sebanyak 37 orang dengan hasil pemeriksaan BTA positifsebanyak 25 orang $(67.6 \%)$ dan BTA negative sebanyak 12 orang $(32.4 \%)$. Sedangkan sebagian kecil responden memiliki luas ventilasi baik sebanyak 19 orang dengan keseluruhan hasil pemeriksaan BTA positif sebanyak 19 orang $(100 \%)$.

Hasil analisis tabel 2 diatas juga menunjukkan nilai koefisien korelasi antara luas ventilasi responden terhadap penyakit TB Paru pada pasien TB Paru di wilayah kerja Puskesmas Panyabungan Jae adalah sebesar 0,005 dengan taraf signifikan $5 \%$ yaitu $p$ Value $<\alpha(0,005<0,05)$, maka $\mathrm{H}_{0}$ ditolak dan $\mathrm{H}_{\mathrm{a}}$ diterima. Artinya terdapat hubungan signifikan antara luasventilasi terhadap penyakit TB Paru pada pasien TB Paru di wilayah kerja Puskesmas Panyabungan Jae.

Berdasarkan tabel 2 diatas diketahui sebagian besar responden memiliki kepadatan kurang baik sebanyak 30 orang dengan hasil pemeriksaan BTA positif sebanyak 20 orang $(66.7 \%)$ dan BTA negative sebanyak 10 orang (33.3\%). Sedangkan sebagian kecil responden memiliki kepadatan baik sebanyak 26 orang dengan hasil pemeriksaan BTA positif sebanyak 24 orang $(92.3 \%)$ dan BTA negative sebanyak 2 orang $(7.7 \%)$.

Hasil analisis tabel 2 diatas juga menunjukkan nilai koefisien korelasi antara kepadatan responden terhadap penyakit TB Paru pada pasien TB Paru di wilayah kerja Puskesmas Panyabungan Jae adalah sebesar 0,020 dengan taraf signifikan $5 \%$ yaitu $p$ Value $<a(0,020<0,05)$, maka $H_{0}$ ditolak dan $H_{a}$ diterima. Artinya terdapat hubungan signifikan antara kepadatan terhadap penyakit TB Paru pada pasien TB Paru di wilayah kerja Puskesmas Panyabungan Jae.

\section{PEMBAHASAN}

\section{Hubungan Pengetahuan Dengan Penyakit TB Paru Pada Pasien TB Paru}

Berdasarkan Hasil penelitian sebagian besar responden memiliki pengetahuan yang kurang mengenai penyakit TB Paru. Hal ini dapat dilihat dari proporsi responden yang memiliki pengetahuan kurang tentang penyakit TB Paru sebanyak 42 orang $(75.0 \%)$ dan responden yang memiliki pengetahuan baik tentang penyakit TB Paru sebanyak 14 orang $(25.0 \%)$.

Menurut Oemarjoedi (dalam Dulistiawati, 2013) pengetahuan adalah faktor penentu bagaimana manusia berfikir, merasa dan bertindak. Sedangkan menurut Rober (2010) secara umum pengetahuan adalah komponenkomponn mental yang dihasilkan dari semua proses apapun, entah lahir dari bawaan atau dicapai lewat pengalaman. Seseorang dapat meningkatkan pengetahuan kesehatan jika mendapatkan informasi yang baik. ${ }^{11}$

Dari hasil analisis bivariat menggunakan program SPSS dapat dilihat nilai koefisien korelasi antara pengetahuan responden 
terhadap penyakit TB Paru pada pasien TB Paru di wilayah kerja Puskesmas Panyabungan Jae adalah sebesar 0,003 dengan taraf signifikan $5 \%$ yaitu $p$ Value $<\alpha$ $(0,003<0,05)$, maka $\mathrm{H}_{0}$ ditolak dan $\mathrm{H}_{\mathrm{a}}$ diterima. Artinya terdapat hubungan signifikan antara pengetahuan terhadap penyakit TB Paru pada pasien TB Paru di wilayah kerja Puskesmas Panyabungan Jae. Hal ini juga didukung dengan hasil pemeriksaan dimana dari 42 orang dengan pengetahuan kurang diantaranya memiliki hasil pemeriksaan BTA positif sebanyak 37 orang (88.1\%) dan BTA negative sebanyak 5 orang (11.9\%). Sedangkan dari 14 orang dengan pengetahuan baik diantaranya memiliki hasil pemeriksaan BTA positif sebanyak 7 orang $(50 \%)$ dan BTA negative sebanyak 7 orang $(50 \%)$. Penelitian ini sesuai dengan penelitian yang dilakukan oleh Sari Anugrah (2012) yang menyatakan seseorang dengan pengetahuan yang buruk tentang TB Paru memiliki risiko 1,886 kali menderita TB Paru dibandingkan dengan seseorang yang memiliki pengetahuan yang baik tentang TB Paru. ${ }^{12}$

Pengetahuan merupakan hal yang penting dalam mengambil tindakan maupun menjalani aktifitas sehari-hari. Seseorang dengan pengetahuan yang baik maka akan mampu mengambil keputusan maupun mengambil tindakan yang baik pula. Begitupun sebaliknya dengan pengetahuan yang kurang. Dalam penelitian ini ditunjukkan bahwa adanya hubungan pengetahuan seseorang terhadap penyakit TB Paru. Ini berarti pengetahuan mereka yang kurang mengenai penyakit TB Paru dan tatalaksananya menjadi salah satu penyebab masih tingginya angka penderita TB Paru di wilayah kerja Puskesmas Panyabungan Jae yaitu sekitar $60 \%$. Pemberian edukasi kepada masyarakat di wilayah kerja Puskesmas Panyabungan Jae tentang penyakit TB Paru dan tatalaksananya merupakan suatu cara untuk meningkatkan pengetahuan yang kurang terhadap penyakit TB Paru. Edukasi bisa melalui promosipromosi kesehatan, konseling dan iklan-iklan tentang penyakit TB Paru dan tatalaksananya. Dengan meningkatnya pengetahuan masyarakat tentang penyakit TB Paru maka secara perlahan akan mengurangi angka kejadian penyakit TB Paru.

Notoatmodjo menyimpulkan bahwa pengetahuan seseorang mempengaruhi perilaku individu, yang artinya semakin tinggi pengetahuan seseorang tentang kesehatan maka akan semakin tinggi pula kesadarannya untuk berperan serta dalam kegiatan kesehatan. Sedangkan menurut pendapat Ejang yang menyatakan bahwa penyakit
Tuberkulosis banyak terdapat pada golongan masyarakat dengan tingkat pengetahuan yang rendah tentang cara-cara hidup sehat. ${ }^{13}$

Penelitian ini sejalan dengan hasil penelitian yang dilakukan oleh Zulaikhah (2019) pada penderita TB Paru di wilayah kerja Puskesmas Bandarharjo Semarang. Penelitian ini dilakukan menggunakan uji Chi Square dengan hasil nilai signifikansi sebesar 0.002 yang berarti terdapat hubungan antara tingkat pengetahuan denagn kejadian transmisi Tuberkulosis Paru di wilayah kerja Puskesmas Bandarharjo Semarang. (14)

\section{Hubungan Sikap Dengan Penyakit TB Paru} Pada Pasien TB Paru

Berdasarkan Hasil penelitian sebagian besar responden memiliki sikap yang negatif mengenai penyakit TB Paru. Hal ini dapat dilihat dari proporsi responden yang memiliki sikap negatif tentang penyakit TB Paru sebanyak 40 orang $(71.4 \%)$ dan responden yang memiliki sikap positif tentang penyakit TB Parusebanyak 16 orang (28.6\%).

Sikap menurut Notoatmodjo (2003) adalah reaksi atau respon seseorang yang masih tertutup terhadap suatu stimulus atau objek. Jadi sikap itu bukanlah tindakan melainkan suatu kesiapan untuk bereaksi terhadap objek di lingkungan sekitar atau tahap penghayatan terhadap suatu objek (11). Sedangkat menurut Mar'at (2000) sikap adalah tingkatan afeksi (perasaan), baik yang bersifat positif maupun negatif dalam hubungannya dengan objek psikologi. Dengan demikian perasaan dalam merespon suatu objek dapat positif yaitu perasaan senang, menerima, terbuka dan dapat negative yaitu perasaan tidak senang, tidak menerima, tdak terbuka. ${ }^{15}$

Dari hasil analisis bivariat menggunakan program SPSS dapat dilihat nilai koefisien korelasi antara sikap responden terhadap penyakit TB Paru pada pasien TB Paru di wilayah kerja Puskesmas Panyabungan Jae adalah sebesar 0,010 dengan taraf signifikan $5 \%$ yaitu $p$ Value $<\alpha(0,010<0,05)$, maka $\mathrm{H}_{\circ}$ ditolak dan $\mathrm{H}_{\mathrm{a}}$ diterima. Artinya terdapat hubungan signifikan antara sikap terhadap penyakit TB Paru pada pasien TB Paru di wilayah kerja Puskesmas Panyabungan Jae. Hal ini sesuai dengan penelitian yang dilakukan oleh Putri (2018) terhadap kejadian Tuberkulosis di kota Pekalongan dengan hasil nilai signifikan $(p=0,009)$ yang berarti adanya hubungan sikap dengan kejadian Tuberkulosis di kota Pekalongan.

Penelitian ini juga didukung oleh hasil pemeriksaan dimana dari 40 orang yang memiliki sikap negatif terhadap penyakit TB Paru diantaranya memiliki hasil pemeriksaan BTA positif sebanyak 35 orang $(87.5 \%)$ dan 
BTA negative sebanyak 5 orang (12.5\%). Sedangkan dari 16 orang yang memiliki sikap positif terhadap penyakit TB Paru diantaranya memiliki hasil pemeriksaan BTA positif sebanyak 9 orang $(56.3 \%)$ dan BTA negative sebanyak 7 orang $(43.8 \%)$.

Penelitian ini menunjukkan bahwa sikap seseorang terhadap suatu objek mampu mempengaruhi peningkatan angka penderita TB Paru di wilayah kerja Puskesmas Panyabungan Jae. Semakin baik sikap seseorang terhadap penyakit di lingkungannya maka akan mengurangi angka kejadian penyakit di lingkungan sekitar mereka. Sekitar $71,4 \%$ responden wilayah kerja Puskesmas Panyabungan Jae memiliki sikap yang negative terhadap penyakit TB Paru dilingkungannya.hal itulah yang menyebabkan masih banyak diantara mereka yang positif BTA setelah dilakukan tes sputum dua kali berturut-turut. Sikap negative itu bisa disebabkan oleh pengetahuan yang kurang terhadap penyakit TB Paru.

Proses pembentukan sikap dapat terjadi karena adanya rangsangan, seperti pengetahuan tentang penyakit TB Paru. Rangsangan tersebut akan menstimulus responden untuk memberikan respon yang positif atau negative. Pendapat Alwi (2003) bahwa pengetahuan sesorang tentang suatu objek mengandung dua aspek yaitu aspek positif dan aspek negative. Kedua aspek ini yang akan menentukan sikap seseorang. Semakin banyak aspek positif dan objek yang diketahui, maka akan menimbulkan sikap makin positif terhadap objek tertentu.

Dengan ini masyarakat di wilayah kerja Puskesmas Panyabungan Jae harus didorong umtuk bersikap positif terhadap penyakit TB Paru diwilayahnya.

Penelitian ini sejalan dengan penelitian Retno dan Florentina (2015) pada penderita Tuberkulosis diwilayah kerja Puskesmas Jagir Kecamatan Wonokromo Kota Surabaya dengan hasil nilai sigmifikan 0,013 yang berarti terdapat hubungan bermakna antara sikap dengan kejadian Tuberkulosis. ${ }^{18}$

\section{Hubungan Tindakan Dengan Penyakit TB Paru Pada Pasien TB Paru}

Berdasarkan tabel Hasil penelitian sebagian besar responden dengan tindakan yang tidak baik mengenai penyakit TB Paru. Hal ini dapat dilihat dari proporsi responden dengan tindakan tidak baik tentang penyakit TB Paru sebanyak 43 orang $(76.8 \%)$ dan responden dengan tindakan baik tentang penyakit TB Paru sebanyak 13 orang (23.2\%). Menurut Notoatmodjo (2007) tindakan secara teori merupakan perubahan perilaku atau adopsi perilaku melalui proses perubahan seperti pengetahuan (knowledge), sikap (attitude) dan praktik (practice). Tindakan yang kurang merupakan factor resiko terjadinya kejadian penyakit Tuberkulosis. ${ }^{19}$

Dari hasil analisis bivariat menggunakan program SPSS dapat dilihat nilai koefisien korelasi antara tindakan responden terhadap penyakit TB Paru pada pasien TB Paru di wilayah kerja Puskesmas Panyabungan Jae adalah sebesar 0,013 dengan taraf signifikan $5 \%$ yaitu $p$ Value $<\alpha(0,013<0,05)$, maka $H_{0}$ ditolak dan $\mathrm{H}_{\mathrm{a}}$ diterima. Artinya terdapat hubungan signifikan antara tindakan terhadap penyakit TB Paru pada pasien TB Paru di wilayah kerja Puskesmas Panyabungan Jae. Hal ini sesuai dengan penelitian ini oleh Putra (2011) dengan nilai $(p=0,028)$ yang berarti adanya hubungan yang signifikan antara tindakan dengan kejadian Tuberkulosis dan penelitian yang dilakukan oleh Bachtiar (2013) dengan nilai $(p=0,008)$ yang menunjukkan adanya hubungan tindakan dengan kejadian Tuberkulosis. ${ }^{20,21}$

Penelitian ini juga didukung oleh hasil pemeriksaan yang dilakukan dimana dari 43 orang dengan tindakan tidak baik diantaranya memiliki hasil pemeriksaan BTA positif sebanyak 37 orang (86.0\%) dan BTA negative sebanyak 6 orang (14.0\%). Sedangkan dari 13 orang dengan tindakan baik diantaranya memiliki hasil pemeriksaan BTA positif sebanyak 7 orang $(53.8 \%)$ dan BTA negative sebanyak 6 orang $(46.2 \%)$.

Dari penelitian ini dapat diketahui bahwa tindakan masyarakat yang kurang menjadi salah satu factor resiko angka kejadian penyakit TB Paru.. Masyarakat di wilayah kerja Puskesmas Panyabungan Jae memiliki tindakan yang kurang terhadap tatalaksana penyakit TB Paru sehingga menyebabkan meningkatnya penularan penyakit di masyarakat hingga menimbulkan tingginya angka kejadian penyakit TB Paru. Masyarakat seharusnya diberikan edukasi mengenai tindakan apa yang harus dilakukan terhadap penyakit TB Paru. Masyarakat bisa diedukasi mulai dengan cara pencegahan penularan penyakit TB Paru seperti menutup mulut saat batuk, penggunaan masker. Masyarakat juga dapat diedukasi mengenai konsumsi obat secara teratur agar penyakit TB Paru dapat segera sembuh dan tidak berulang.

Penelitian ini sesuai dengan penelitian yang dilakukan oleh Retno dan Florentina (2015) pada penderita Tuberkulosis diwilayah kerja Puskesmas Jagir Kecamatan Wonokromo Kota Surabaya, diperoleh analisis data menunjukkan nilai $\mathrm{p}=0,001$ yang bermakna adanya hubungan antara tindakan dengan kejadian Tuberkulosis. ${ }^{18}$ Penelitian 
Putri (2018) juga menunjukkan adanya hubuungan yang signifikan antara tindakan tentang Tuberkulosis dengan kejadian Tuberkulosis di Kota Pekalongan $(\mathrm{p}=0,008){ }^{16}$

\section{Hubungan Luas Ventilasi Dengan Penyakit} TB Paru Pada Pasien TB Paru

Berdasarkan Hasil penelitian sebagian besar responden memiliki luas ventilasi yang kurang baik. Hal ini dapat dilihat dari proporsi responden yang memiliki luas ventilasi rumah yang kurang baik yaitu sebanyak 37 orang $(66.1 \%)$,dan responden yang memiliki luas ventilasi rumah yang baik yaitu sebanyak 19 orang (33.9\%).

Ventilasi adalah usaha untuk memenuhi kondisi atmosfer yang menyenangkan dan menyehatkan manusia. ${ }^{22}$ Ventilasi yang tidak memadai akan mengakibatkan meningkatnya kelembapan udara dalam ruangan, serta kondisi tersebut merupakan kondisi yang baik sebagai media perkembang biakan kuman patogen. ${ }^{23}$

Dari hasil analisis bivariat menggunakan program SPSS dapat dilihat nilai koefisien korelasi antara luas ventilasi terhadap penyakit TB Paru pada pasien TB Paru di wilayah kerja Puskesmas Panyabungan Jae adalah sebesar 0,005 dengan taraf signifikan $5 \%$ yaitu $p$ Value $<$ a $(0,005<0,05)$, makaH $_{0}$ ditolak dan $\mathrm{H}_{\mathrm{a}}$ diterima. Artinya terdapat hubungan signifikan antara luasventilasi terhadap penyakit TB Paru pada pasien TB Paru di wilayah kerja Puskesmas Panyabungan Jae. Hal ini sesuai dengan penelitian Dwi (2013) yang hasilnya adalah adanya pengaruh luas ventilasi terhadap kejadian TB Paru di wilayah kerja Puskesmas Sukoharjo Kabupaten Sukoharjo (pvalue $=0,00{ }^{24}$

\section{Hubungan Kepadatan Hunian Dengan Penyakit TB Paru Pada Pasien TB Paru}

Berdasarkan Hasil penelitian sebagian besar responden memiliki kepadatan yang kurangbaik. Hal ini dapat dilihat dari proporsi responden yang memiliki kepadatan yang kurang baik yaitu sebanyak 30 orang $(53.6 \%)$ dan responden yang memiliki kepadatan yang baik yaitu sebanyak 26 orang (46.4\%).

Kepadatan hunian merupakan salah satu indikator pemicu tingginya tingkat penularan TB Paru. Kepadatan penghuni dalam satu rumah tinggal akan memberikan pengaruh bagi penghuninya. Luas rumah yang tidak sebanding dengan jumlah penghuninya akan menyebabkan berjubel (over crowded). Hal ini tidak sehat karena disamping menyebabkan kurangnya konsumsi oksigen, juga apabila salahsatu anggota keluarga terkena penyakit infeksi, terutama tuberkulosis akan mudah menular kepada anggota keluarga lain. ${ }^{19}$
Dari hasil analisis bivariat menggunakan program SPSS dapat dilihat nilai koefisien korelasi antara kepadatanterhadap penyakit TB Paru pada pasien TB Paru di wilayah kerja Puskesmas Panyabungan Jae adalah sebesar 0,020 dengan taraf signifikan $5 \%$ yaitu $p$ Value < a $(0,020<0,05)$, maka $H_{0}$ ditolak dan $H_{a}$ diterima. Artinya terdapat hubungan signifikan antara kepadatan terhadap penyakit TB Paru pada pasien TB Paru di wilayah kerja Puskesmas Panyabungan Jae. Hal inisesuai dengan penelitian Sugiharto (2004) dimana terdapat hubungan antara kepadatan hunian ruang tidur dengan kejadian TB Paru di Puskesmas Jenggot dengan nilai $p$ value berdasarkanuji Chi-Square sebesar 0.001. ${ }^{25}$

Kepadatan hunian rumah mampu menjadikannya salah satu factor resiko terjadinya penyakit. Khususnya penyakit TB Paru. Penularan mikroorganisme TB Paru akan sangat cepat berlangsung bila didalam suatu rumah yang memiliki jumlah penguin yang cukup padat.

\section{KESIMPULAN}

Berdasarkan hasil penelitian Hubungan Perilaku dan Lingkungan Rumah dengan Pasien TB Paru di Wilayah Kerja Puskesmas Panyabungan Jae Tahun 2019, maka dapat di simpulkan bahwa Ada hubungan antara pengetahuan, sikap, tindakan, luas ventilasi, dan kepadatan dengan penyakit TB Paru pada pasien TB Paru di wilayah kerja Puskesmas Panyabungan Jae.

\section{DAFTAR PUSTAKA}

1. Kemenkes $\mathrm{R}$ I. Tuberkulosis. Jakarta; 2016.

2. Kemenkes $\mathrm{R}$ I. Pedoman Nasional Pengendalian Tuberkulosis. Jakarta; 2014.

3. Kemenkes $\mathrm{R}$ I. Profil Kesehatan Indonesia Tahun 2017. In 2017. Tersedia pada:

www.depkes.go.id.donwolad.pusadtin

4. Kemenkes $\mathrm{R}$ I. Profil Kesehatan Indonesia Tahun 2016. Jakarta; 2016.

5. Kemenkes R I. Ditjen P2P. Jakarta; 2018.

6. Kemenkes R I. Ditjen P2P. Jakarta; 2019.

7. Depkes R I. Profil Kesehatan Provinsi Sumatera Utara Tahun 2016. In Sumatera Utara: Depkes R I; 2017.

8. DinKes Kota Medan. Profil Kesehatan Kab/Kota. Medan; 2017.

9. Dewi EF, Suhartono, Adi MS. HUBUNGAN FAKTOR LINGKUNGAN RUMAH DENGAN KEJADIAN TB PARU DI KOTA MAGELANG. J Kesehat Masy. 2016;4(2):149-59.

10. Wenas AR, Kandou GD, Rombot D V. HUBUNGAN PERILAKU DENGAN 
KEJADIAN PENYAKIT TB PARU DIDESA WORI KECAMATAN WORI KABUPATEN MINAHASA UTARA. urnal Kedokt Komunitas dan Trop. 2015;3(2):82-9.

11. Notoatmodjo S. Pendidikan Kesehatan dan IImu Perilaku. Jakarta: Rineka Cipta; 2003.

12. ANUGRAH S. HUBUNGAN ANTARA TINGKAT PENGETAHUAN TENTANG TB PARU, STATUS GIZI, RIWAYAT KONTAK KELUARGA, DAN RIWAYAT MEROKOK PASIEN YANG BEROBAT KE UP4 DENGAN KEJADIANNYA DI UP4 KOTA PONTIANAK. 2012;

13. Soejadi. Analisis faktor-faktor yang mempengaruhi kejadian kasus tuberculosis paru. Politeknik Kesehatan Depkes Medan; 2007.

14. Zulaikhah. Hubungan Pengetahuan, Perilaku dan Lingkungan Rumah dengan Kejadian Transmisi Tuberkulosis Paru di Wilayah Kerja Puskesmas Bandarharjo Semarang. J Kesehat Lingkung Indones. 2019;18(2).

15. Mar'at. Sikap Manusia, Perubahan, serta Pengukurannya. Jakarta: Ghalia Indonesia; 2000.

16. Sari PK. HUBUNGAN ANTARA TINGKAT PENGETAHUAN, SIKAP DAN TINDAKAN TENTANG TUBERKULOSIS DENGAN KEJADIAN TUBERKULOSIS DI KOTA PEKALONGAN. UNIVERSITAS MUHAMMADIYAH SURAKARTA; 2018.
17. Alwi. Kamus Besar Bahasa Indonesia. Jakarta: Balai Pustaka; 2003.

18. Agustin RA, Sustini F. HUBUNGAN PERILAKU PENDERITA DENGAN KEJADIAN TUBERKULOSIS DI WILAYAH KERJA PUSKESMAS JAGIR KECAMATAN WONOKROMO KOTA SURABAYA. 2015;

19. Notoatmodjo S. Promosi kesehatan dan Ilmu perilaku. 2012: Rineka Cipta; 2007.

20. Putra. Hubungan Perilaku dan Kondisi Sanitasi Rumah dengan Kejadian TB Paru di Wilayah Kota Solok. 2011;

21. Bactiar. Hubungan Perilaku dan kondisi Lingkungan Fisik Rumah dengan Kejadian TB Paru di Kota Bima Provinsi NTB. 2013;

22. Nurhidayah. Hubungan antara Karakteristik Lingkungan Rumah dengan Kejadian Tuberkulosis pada Anak di Kecamatan Paseh Kabupaten Sumedang. 2007.

23. Simbolon. Faktor Risiko Tuberculosis Paru di Kabupaten Rejang Lebong. J Kesehat Masy Nas. 2007;2(3):112-9.

24. MURTININGSIH DA. Pengaruh luas ventilasi terhadap kejadian tb paru di wilayah kerja puskesmas sukoharjo tahun 2013. 2013;

25. Sugiharto. Hubungan Kepadatan Hunian Rumah dengan Kejadian Penyakit Tuberkulosis Paru di Puskesmas Jenggot. Universitas Diponegoro; 2004. 